\title{
IQTISHODUNA
}

Vol. 17 (2), 2021

P-ISSN: 1829-524X, E-ISSN: 26143437

\section{Moderasi Ukuran Perusahaan pada Profitabilias, Leverage dan Rasio Aktivitas terhadap Kebijakan Dividen}

\author{
Ira Puspita Setyaningsih ${ }^{1}$, Agus Sucipto ${ }^{2}$ \\ 1,2Universitas Islam Negeri Maulana Malik Ibrahim Malang, Jl. Gajayana, \\ Malang, Indonesia
}

$凶$ Corresponding Author:

Nama Penulis: Ira Puspita Setyaningsih

E-mail: irapuspitaa282@gmail.com

\begin{abstract}
Dividend policy is the company's policy in determining how much profit will be paid as dividends to investors. Dividend policy is the most important determination for a company because it is not only a source of investment profit, but also shows the company's performance. In making dividend payment policies the company considers financial ratios that can have an influence on dividend payment policies. The purpose of this study is to examine the role of company size to moderate the effect of profitability ratios, leverage ratios and activity ratios on dividend policy. This study makes the service sector companies listed on the Indonesia Stock Exchange in 2014-2018 as a research population of 289 companies with the research sample taken using purposive sampling technique as many as 69 companies. This research method uses descriptive quantitative method. Data analysis was processed using Partial Least Squares (PLS) analysis with Warp-Pls 6.0 software. The results of this study indicate that the profitability ratios and activity ratios affect the dividend policy positively and significantly, while the leverage ratio affects the dividend policy negatively and significantly. Firm size strengthens the effect of profitability ratios on dividend policy but does not moderate the effect of leverage ratios and activity ratios on dividend policy.
\end{abstract}

Keywords: Profitability Ratio, Leverage Ratio, Activity Ratio, Firm Size, Dividend Policy

\begin{abstract}
Abstrak: Kebijakan dividen adalah kebijaksanaan perusahaan dalam menentukan seberapa besar keuntungan yang akan dibayar sebagai dividen kepada investor. Kebijakan dividen menjadi ketapan yang terpenting bagi perusahaan sebab tidak hanya menjadi sumber keuntungan investonya, namun juga menunjukan kinerja perusahaan. Dalam pengambilan kebijakan pembayaran dividen perusahaan mempertimbangan rasio keuangan yang dapat memiliki pengaruh terhadap kebijakan pembayaran dividen. Tujuan penelitian ini adalah menguji peran ukuran perusahaan memoderasi pengaruh rasio profitabilitas, rasio leverage dan rasio aktivitas terhadap kebijakan dividen. Penelitian ini menjadikan perusahaan sector jasa yang terdaftar di BEI tahun 2014-2018 sebagai populasi penelitian yaitu sebanyak 289 perusahaaan dengan sampel penelitian yang telah diambil menggunakan teknik purposive sampling yaitu sebanyak 69 perusahaan. Metode penelitian ini menggunakan metode kuantitatif deskriptif. Analisi data diolah menggunakan analisi Partial Least Squares (PLS) dengan alat software Warp-Pls 6.0. Hasil penelitian ini menunjukan bahwa rasio profitabilitas
\end{abstract}


Ira Puspita Setyaningsih, Agus Sucipto

dan rasio aktivitas mepengaruhi kebijakan dividen secara posited dan signifikan, sedangkan rasio leverage mempengaruhi kebijakan dividen secara nnegatif dan signifikan. Ukuran perusahaan memperkuat pengaruh rasio profitabilitas terhadap kebijakan dividen namun tidak memoderasi pengaruh rasio leverage dan rasio aktivitas terhadap kebijakan dividen.

Kata kunci: Rasio Profitabilitas, Rasio Leverage, Rasio Aktivitas, Ukuran Perusahaan, Kebijakan Dividen

| Submit 5 Mei 2020 |Diterima 23 September 2021 | Terbit 31 Oktober 2021 |

\section{Cara mensitasi:}

Setyaningsih, I. P \& Sucipto, A. (2021). Moderasi Ukuran Perusahaan pada Profitabilias, Leverage dan Rasio Aktivitas terhadap Kebijakan Dividen. Iqtishoduna. Vol. 17 (2): pp 141-162

\section{PENDAHULUAN}

Kegiatan investasi di pasar modal bukanlah hal yang asing lagi di Indonesia dimana pasar modal sudah ada sejak tahun 1912 pada jaman belanda dan terus berkembang sampai sekarang tercatat sekitar 671 perusahaan telah tergabung di Bursa Efek Indonesia (BEI). Perkembangan di pasar modal Indonesia ini tidak lepas dari peran investor, baik investor lokal maupun investor asing. Dalam melakukan investasi, seorang investor tentu memiliki tujuan yang ingin dicapai yaitu mendapatkan keuntungan salah satunya yaitu berasal dari pembayaran dividen tunai. Kebijakan pembayaran dividen merupakan keputusan terpenting bagi perusahaan karena menjadi sumber keuntungan investor dan juga menunjukan kinerja perusahaan (AlKayed, 2017). Menurut Brealey, Myers, and Marcus (2008:51) kebijakan pembayaran dividen yang tinggi mahal mahal bagi perusahaan dengan kondisi kas yang tidak cukup untuk membayar dividend, hanya perusahaan dengan kas yang cukup yang dapat menunjukan masa depan mereka yang bagus dengan melakukan pembayaran dividen. Semakin tinggi dividen yang dibayarkan perusahaan dianggap sebagai berita yang baik oleh para investor begitu juga sebaliknya, ketika perusahaan melakukan pemotongan dividen dianggap sebagai berita buruk. 
Moderasi Ukuran Perusahaan pada... Tranformasi perekonomian Indonesia berlangsung relatif cepat sejak 2010

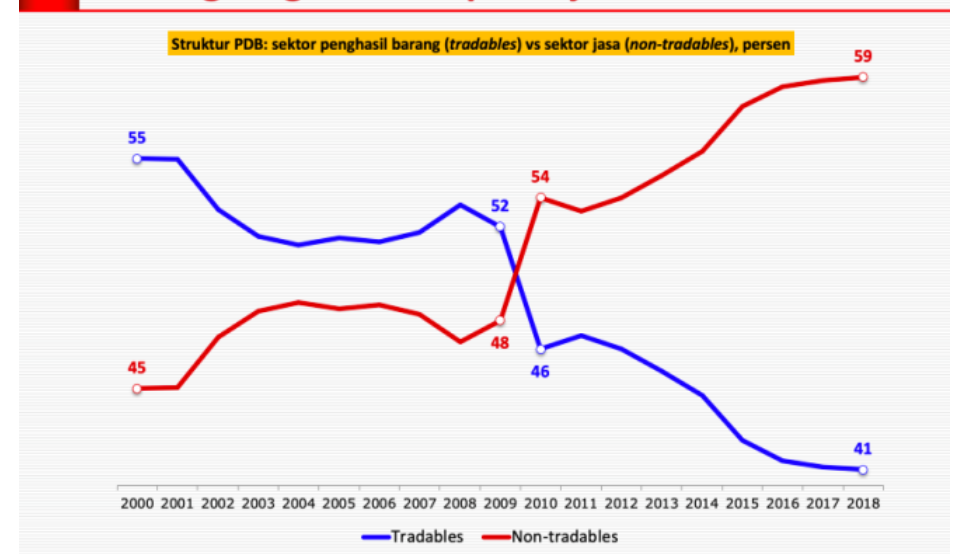

Gambar 1. Transformasi perekonomian Indonesia

Sektor jasa merupakan penopang perekonomian negara dan mulai mendominasi kondisi perekonomian nasional. Sektor ini terus mengalami peningkatan pesat sejak tahun 2012 sampai sekarang dengan kontribusi tertinggi pada tahun 2018 sebesar 50 \%. Hal ini terjadi karena ditopang dengan semakin banyaknya investasi pada sektor jasa, selain itu sektor jasa tidak lagi bergantung pada pemerintah domestik sehingga semakin berkembang pesatnya teknologi informasi, internet dan digitalisasi menjadikan semakin banyak sector jasa yang dapat diperdagangkan. Selain itu biaya yang digunakan juga semakin turun untuk memperdagangkan jasa karena adanya teknologi digital, dan juga semaik produktifnya sektor jasa saat ini dengan adanya perkembangan teknologi (Hidayatullah, 2019). Sektor jasa berfungsi untuk menjadi perantara berbagai sektor dengan konsumen maupun modal. Dilansir dari opini.harianjogja.com, bahwa sekitar 34\% dari total output sektor jasa di Indonesia dipakai untuk input antara pada aktivitas produksi dan kontribusi sektor jasa terhadap total input antara yang mencapai 16\%, dimana sektor-sektor yang memperoleh input dari sektor jasa yaitu sektor pertanian, pertambangan, manufaktur dan sektor jasa lainnya. Melihat potensi pertumbuhan yang sangat baik pada sektor jasa tentu menarik minat investor untuk melakukan investasi pada perusahaanperusahaan yang tergabung dalam sektor ini mengingat tujuan utama investor dalam berinvestasi yaitu mendapatkan keutungan yang salah satunya besarsal berasal dari pembayaran dividen tunai. Pertumbuhan yang selalu meningkat setiap tahunnya menunjukkan bahwa perusahaan yang tergabung dalam sektor ini memiliki kinerja yang baik pula, sehingga kemampuan perusahaan dalam melakukan pembayaran dividen juga akan semakin baik. Besarnya dividen yang akan dibayarkan perusahaan dipengaruhi oleh berbagai faktor, salah satunya yaitu rasio keuangan perusahaan. Rasio keuangan yang diduga memiliki pengaruh terhadap kebijakan dividen ialah rasio profitabilitas, rasio leverage dan rasio aktivitas.

Rasio profitabilitas fokus pada perhitungan laba perusahaan dan menunjukan kemampuan perolehan laba perusahaan dari kegiatan bisnisnya. Rasio ini dapat digunakan investor untuk melihat tingkat efisiesnsi 
Ira Puspita Setyaningsih, Agus Sucipto

perusahaan dalam menggunakan asetnya pada kegiatan operasi guna memperoleh laba. Penelitian yang dilakukan oleh Singla and Samanta (2018); Abor and Bokpin (2010); Mardiyati, Nusrati, and Hamidah (2014); Lestari (2017); Daud (2015); Narindro and Basri (2019); Thakur and Kannadhasan (2018); Issa (2015); Ahmad and Wardani (2014); Ahmed, Rafay, and Ahmed (2018); Arko et al. (2014); Fitri, Hosen, And Muhari (2016); Muhammadinah and Jamil (2015) dan Tahu et al. (2017) menemukan kebijakan dividen diperngaruhi secara positif dan signifikan oleh profitabilitas, jika tingkat rasio profitabilitas tinggi maka jumlah dividen yang akan dibayarkan juga akan semakin besar. Namun, hasil penemuan Al-Kayed (2017); Ali, Fengju, and Goncalves De Andrade (2015); Arseto and Jufrizen (2018) dan Marlim and Arifin (2015) menyatakan bahwa kebijakan dividen dipengaruhi secara negative dan signifikan oleh rasio profitabilitas, jika tingkat rasio profitabilitas tinggi maka dividen yang dibayarkan perusahaan semakin kecil. Hasil yang berbeda juga ditemukan oleh Enow and Isaacs (2018); Ahmed (2015) dan Mehta (2012) bahwa kebijakan dividen dipengaruhi rasio profitabilitas secara negative namun tidak signifikan, sebaliknya Simanjuntak (2016) menyatakan kebijakan dividen dipengaruhi rasio profitabilitas secara positif dan tidak signifikan.

Rasio leverage dipakai untuk melihat pengelolaan total utang perusahaan, semakin besar nilai leverage menunjukan gejala yang kurang baik pada suatu perusahaan. Perusahaan dengan tingkat utang besar dan harus dibayar segera, akan mengurangi jumlah pembayaran dividennya atau menunda pembayarannya (Gumanti 2013:83). Penelitian yang dilakukan oleh Al-Kayed (2017) dann Khan and Shamim (2017) menemukan kebijakan dividen dipengaruhi secara positif dan signifikan oleh rasio leverage, jika tingkat leverage yang tinggi maka akan semakin besar pula pembayaran dividennya. Hasil lain ditunjukan pada penelitian Al-Kayed (2017); Yusof and Ismail (2016); Hasnawati (2017); Jabbouri (2016); Kuzucu (2015); Ahmad and Wardani (2014); Trisna and Gayatri (2019); Arko et al. (2014) dan Kaźmierska-Jóźwiak (2015) menemukan kebijakan dividen dipengaruhi secara negatf dan signifikan oleh rasio leverage, jika tingkat leverage tinggi maka akan semakin pembayaran dividennya. Hasil yang berbeda juga ditunujukan oleh Singla and Samanta (2018) bahwa kabijakan dividen dipengaruhi secara positif namun tidak signifikan oleh rasio leverage, sedangkan Lestari (2017) dan Simanjuntak (2016) menemunkan kabijakan dividen dipengaruhi secara negative dan tidak signifikan oleh rasio leverage.

Rasio aktivitas digunakan untuk menilai pennggunaan sumber daya yang dimiliki perusahaan secara efektif. Semakin baik kinerja perusahaan akan berpengaruh pada semakin besarnya jumlah dividen yang dibayarkan (Sartono 2012:118). Penelitian yang dilakukan oleh Muhammadinah and Jamil (2015); Firdaus and Handayani (2019); Simanjuntak (2016); Sampurna and Widyarti (2015); Purwanti and Sawitri (2011) dan Sabri, Deviyanti, and Kurniawan (2018) menyatakan kebijakan dividen dipengaruhi secara positif dan signifikan oleh rasio aktivias, jika tingkat aktivitas tinggi maka jumlah dividen yang dibagikan juga akan semakin besar. Penemuan tersebut bertolak belakang dengan penelitian Mardiyati, Nusrati, and Hamidah (2014); Marlim and Arifin (2015) dan Rahmawati, Saerang, and Rate (2014) yang menyatakan 
Moderasi Ukuran Perusahaan pada... kebijakan dividen dipengaruhi secara negative dan signifikan oleh rasio aktivitas, jika tingkar aktivitas tinggi maka dividen yang akan dibarkan perusahaan akan semakin kecil. Hasil penelitian yang berbeda juga dikemukakan oleh Nerviana (2015) dan Handayani, Indarti, and Listiyowati (2019) yaitu rasio aktivitas mempengaruhi kebijakan dividen secara positif amun tidak signifikan. Sedangkan Tahu et al. (2017) menmukan pengeruh negative dan tidak signifikan rasio aktivitas terhadap kebijakan dividen.

Berdasarkan peneitian terdahulu terkait pengaruh rasio profitabilitas, rasio leverage dan rasio aktivitas terhadap kebijakan dividen ditemukan hasil yang tidak sama. Penelitian ini menambahkan variabel moderasi ukuran perusahaan untuk memperkuat pengaruh rasio keuangan terhadap kebijakan dividen. Ukuran perusahaan menggambarkan besar kecilnya ukuran suatu perusahaan. Perusahaan yang berukuran besar dianggap telah stabil sehingga aksesnya ke pasar modal untuk mencari tambahan modal lebih mudah, sedangkan berusahaan yang masih baru dan berukuran kecil akan lebih sulit dalam mencari tambahan modal di pasar modal. Hasil penelitian Baker et al. (2019); Singla and Samanta (2018); Dewasiri et al. (2019); Yusof and Ismail (2016); Hasnawati (2017); Wahyuliza and Fahyani (2019); Lestari (2017); Jabbouri (2016); Patra, Poshakwale, and Ow-Yong (2012); Kuzucu (2015); Ahmad and Wardani (2014); Arko et al. (2014) dan Mehta (2012) menunjukan bahwa kebijakan dividen dipengaruhi ukuran perusahaan secara positif dan signifikan, sehingga penggunaan ukuran perusahaan diharapkan dapat memoderasi pengaruh rasio profitabilitas, rasio leverage dan rasio aktivitas terhadap kebijakan dividen. Hasil penelitian Arseto and Jufrizen (2018) menemukan ukuran perusahaan memoderasi hubungan profitabilitas terhadap kebijakan pembayaran dividen. Perusahaan yang berukuran besar memiliki jumlah asset yang tinggi, sehingga dengan pengelolaan aset yang baik tentu perusahaan akan memperoleh keuntungan yang besar pula dan dapat memperbesar jumlah dividen yang akan dibayarkan perusahaan. Penelitian lain yang menggunakan ukuran perusahaan sebagai moderating dilakukan oleh Trisna and Gayatri (2019) dengan hasil ukuran perusahaan berpengaruh signifikan dan memperlemah hubungan leverage terhadap kebijakan dividen. Oleh karena itu penelitian ini ingin melihat peran ukuran perusahaan dalam memoderasi pengaruh rasio profitabilitas, rasio leverage dan rasio aktivitas terhadap kebijakan dividen pada perusahaan jasa yang terdaftar di BEI tahun 2014-2018.

\section{KAJIAN PUSTAKA}

\section{Rasio Profitabilitas terhadap Kebijakan Dividen}

Rasio profitabilitas dimanfaatlam untuk menilai efektif atau tidaknya manajemen secara keseluruhan dengan melihat besarnya tingkat laba bersih yang dihasilkan dari kegiatan investasi maupun penjualan perusahaan (Fahmi 2014:81). Return on assets (ROA) digunakan sebagai alat ukur profitabilitas. Rasio ini menunjukan efektifitas perusahaan dalam menghasilkan laba dengan memanfaatkan asset yang dimiliknya. Pengelolaan asset secara efektif dan efisien pada suatu perusahaan dapat membuat perolehan laba atau keuntungan perusahaan tersebut menjadi stabil. Besarnya perolehan laba 
Ira Puspita Setyaningsih, Agus Sucipto

perusahaan yang dicerminkan oleh nilai profitabilitas menunjukan besarnya kemampuan suatu perusahaaan untuk membayarkan dividen sebab dividen yang akan dibagikan di ambil dari perolehan laba bersih perusahaan. Nilai return on assets yang semakin besar memungkinkan perusahaan meningkatkan permbayaran dividennya (Sartono 2012:122).

Menurut penelitian yang dilakukan oleh Singla and Samanta (2018); Abor and Bokpin (2010); Mardiyati, Nusrati, and Hamidah (2014); Lestari (2017); Daud (2015); Narindro and Basri (2019); Thakur and Kannadhasan (2018); Issa (2015); Ahmad and Wardani (2014); Ahmed, Rafay, and Ahmed (2018); Arko et al. (2014); Fitri, Hosen, And Muhari (2016); Muhammadinah and Jamil (2015); Tahu et al. (2017) menemukan kebijakan dividen diperngaruhi secara positif dan signifikan oleh profitabilitas, jika tingkat rasio profitabilitas tinggi maka jumlah dividen yang akan dibayarkan juga akan semakin besar. Nilai return on asset yang tinggi dapat menarik investor untuk melakukan investasi dengan harapan memperoleh dividen yang tinggi pula.

H1: Profitabilitas memiliki pengaruh positif signifikan terhadap kebijakan dividen.

\section{Rasio Leverage terhadap Kebijakan Dividen}

Bagi pemegang saham, rasio leverage di anggap sangat penting. Rasio ini menunjukan kesanggupan perusahaan memenuhi total utangnya (Hery 2016:162). Pembayaran dividen oleh perusahaan akan semakin turun ketika penggunaan utangnya tinggi, sebab sebagian besar perolehan laba digunakan untuk memenuhi hutangnya. Perusahaan dengan tingkat utang besar dan harus dibayar segera, akan mengurangi jumlah pembayaran dividennya atau menunda pembayarannya (Gumanti 2013:83).

Menurut penelitian yang dilakukan oleh Al-Kayed (2017); Yusof and Ismail (2016); Hasnawati (2017); Jabbouri (2016); Kuzucu (2015); Ahmad and Wardani (2014); Trisna and Gayatri (2019); Arko et al. (2014) dan Kaźmierska-Jóźwiak (2015) menemukan kebijakan dividen dipengaruhi secara negatf dan signifikan oleh rasio leverage. Perusahaan dengan rasio leverage yang tinggi akan menunrunkan jumlah dari dividen yang dibayarkan perusahaan kepada investor. Hal tersebut menunjukan bahwa rasio leverage yang semakin tinggi pada suatu perusahaan akan mengurangi jumlah pembayaran dividen perusahaan sehingga investor akan sangat berhati-hati dalam menginvestasikan dananya pada perusahaan tersebut. Hipotesis kedua yang diambil berdasarkan penelitian diatas ialah:

H2: Leverage memiliki pengaruh negative signifikan terhadap kebijakan dividen.

\section{Rasio Aktivitas terhadap Kebijakan Dividen}

Rasio aktivitas dipakai untuk menilai penggunaan aktiva perusahaan, apakah sudah efektif atau belum (Kasmir 2012:114). Total asstes turnover adalah salah satu rasio akitivas yang menunjukan perbandingan total aktiva dengan tingkat penjualan perusahaan. Rasio ini menggambarkan besarnya peredaran akitva atau asset pada suatu perusahaan, apabila akivitas perusahaan semakin meningkat maka laba yang dihasilkan juga mengalami peningkatan (Simanjuntak, 2016). Semakin tinggi efektifitas perusahaan 
Moderasi Ukuran Perusahaan pada... dalam menggunakan asetnya untuk meningkatkan penjualan, diharapkan dapat meningkatkan perolehan laba perusahaan sehingga kinerja perusahaan akan meningkat. Semakin baik kinerja perusahaan akan berpengaruh pada semakin besarnya jumlah dividen yang dibayarkan (Sartono 2012:118).

Menurut hasil penelitian yang dilakukan oleh Muhammadinah and Jamil (2015); Firdaus and Handayani (2019); Simanjuntak (2016); Sampurna and Widyarti (2015); Purwanti and Sawitri (2011) dan Sabri, Deviyanti, and Kurniawan (2018) menyatakan kebijakan dividen dipengaruhi secara positif dan signifikan oleh rasio aktivitas. Hal tersebut terjadi karea kemampuan perusahaan yang baik dalam mendistribusikan aktiva yang dimilikinya, sehingga tingkat penjualan perusahaan tersebut akan mengalami peningkatan dan memacu peningkatan laba yang besar serta dapat menopang perusahaan dalam melaksanakan kewajibannya kepada para pemegang saham untuk melaksanakan pembayaran dividen. Hipotesis ketiga yang diambil berdasarkan penelitian diatas adalah:

H3: Rasio aktivitas memiliki pengaruh positif signifikan terhadap kebijakan dividen.

\section{Ukuran Perusahaan Memoderasi Pengaruh Rasio Profitabilitas terhadap Kebijakan Dividen}

Rasio profitabilitas mengukur kemampuan perusahaan dalam memeproleh laba usaha (Tahu et al., 2017). Nilai profitabilitas perusahaan yang tinggi mencerminkan semaikin baik kinerjanya dan asset yang dimemiliki juga cukup untuk membayar dividen. Jika profitabilitas perusahaan terus mengalami kenaikan maka, pembayaran dividen juga semakin besar. Perusahaan yang stabil tingkat keuntungannya setiap tahun dapat menjadi acuan bagi investor sehingga yakin berinvestasi, sebaliknya jika suatu perusahaan selalu rugi tentu investor akan enggan melakukan investasi karena investor berinvestasi untuk mendapatkan keuntungan yang besar bukan sebaliknya.

Menurut Arseto and Jufrizen (2018) ukuran perusahaan menunjukan jumlah dari asset yang dimiliki perusahaan, sehingga semakin besar ukuran suatu peruahaan menandakan bahwa asset yang dimiliki juga semakin besar selain itu dana yang diperlukan perusahaan dalam melakukan kegiatan operasi juga lebih besar, begitu sebaliknya. Perusahaan yang berukuran besar memiliki jumlah asset yang tinggi, sehingga dengan pengelolaan aset yang baik tentu perusahaan akan memperoleh keuntungan yang besar pula dan dapat memperbesar jumlah dividen yang akan dibayarkan perusahaan.

Hasil penelitian Arseto and Jufrizen (2018) menyatakan bahwa ukuran perusahaan memoderasi hubungan profitabilitas terhadap kebijakan dividen. Oleh karena itu penggunaan ukuran perusahaan sebagai moderating hubungan antara profitabilitas terhadap kebijakan dividen diharapkan dapat memoderasi hubungan antara keduanya. Hipotesis keempat yang di ambil berdasarkan penelitian tersebut adalah:

H4: Ukuran perusahaan mampu memoderasi hubungan profitabilitas terhadap kebijakan dividen 
Ira Puspita Setyaningsih, Agus Sucipto

Ukuran Perusahaan Memoderasi Pengaruh Rasio Profitabilitas terhadap Kebijakan Dividen

Menurut Singla and Samanta (2018) leverage merupaakan faktor penting yang dipertimbangkan dalam penetapan kebijakan dividen. Tingkat leverage yang tinggi meningkatkan biaya transaksi dan risiko perusahaan, sehingga perusahaan yang mampu memenuhi utangnya tanpa harus menguragi jumlah dividennya adalah perusahaan yang berukuran besar. Perusahaan kecil dengan tingkat leverage yang tinggi akan memangkas jumlah dividennya atau menunda pembayarannya karena biaya eksternal perusahaan yang semakin tinggi. Perusahaan dengan ukuran besar cenderung memiliki jumlah asset yang besar dan mampu memenuhi utangnya tanpa harus memangkas jumlah dividennya, begitu sebaliknya perusahaan yang berukuran kecil akan kesulian dalam melunasi utangya sehinnga akan menurangi jumlah pembayaran dividennya. Hasil penelitian Trisna and Gayatri (2019) menunjukan bahwa pengaruh leverage terhadap kebijakan dividen mampu dimoderasi oleh ukuran perusahaan. Hipotesis kelima yang di ambil berdasarkan penelitian tersebut adalah:

H5: Ukuran perusahaan mampu memoderasi hubungan leverage terhadap kebijakan dividen.

\section{Ukuran Perusahaan Memoderasi Pengaruh Rasio Aktivitas terhadap Kebijakan Dividen}

Menurut Horne and Wachowicz Jr (2012:212) yang dimaksud dengan rasio aktivitas ialah rasio yang mengukur besarnya efektitas penggunaan berbagai aktiva pada suatu perusahaan. Rasio ini digunakan untuk menilai seberapa efektif pennggunaan sumber daya yang dimiliki perusahaan. Rasio aktivitas yang diukur menggunakan Total Assets Turnover menggambarkan besarnya perputaran asset atau aktiva pada suatu perusahaan, jika aktivitas perusahaan semakin besar maka perolehan laba atau keuntungan juga akan mengalami peningkatan. Peningkatan perolehan laba perusahaan dapat memperbesar jumlah pembayaran dividen perusahaan kepada investor yang di gambarkan oleh nilai Dividend Pyout Ratio.

Sementara ukuran perusahaan mecerminkan besarnya total aset perusahaan. Perusahaan yang berukuran ukuran besar menandakan bahwa jumlah assetnya tinggi sehingga kemampuan pembayaran dividen perusahaan akan meningkat (Lestari, 2017). Berdasarkan hasil penelitian Baker et al. (2019); Singla and Samanta (2018); Dewasiri et al. (2019); Yusof and Ismail (2016); Hasnawati (2017); Wahyuliza and Fahyani (2019); Lestari (2017); Jabbouri (2016); Patra, Poshakwale, and Ow-Yong (2012); Kuzucu (2015); Ahmad and Wardani (2014); Arko et al. (2014) dan Mehta (2012) menunjukan bahwa kebijakan dividen dipengaruhi ukuran perusahaan secara positif dan signifikan, maka penggunaan ukuran perusahaan sebagai moderating pengaruh rasio aktivitas terhadap kebijakan dividen diharapkan dapat memoderasi hubungan antara keduanya. Hipotesis keenam yang di ambil berdasarkan penelitian tersebut adalah:

H6: Ukuran perusahaan mampu memoderasi hubungan rasio aktivitas terhadap kebijakan dividen. 
Moderasi Ukuran Perusahaan pada ...

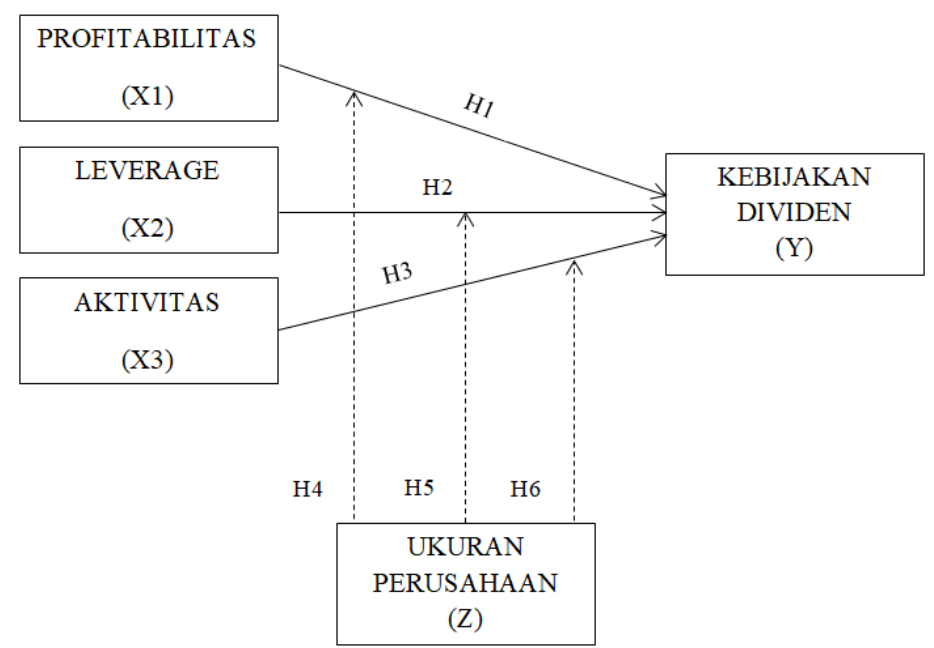

Gambar 2. Model Hipotesis

\section{METODE PENELITIAN}

Jenis penelitian kuantitatif dengan penndekatan deskriptif dipilih dalam penelitian ini dengan jumlah populasi sebanyak 289 perusahaan jasa yang terdaftar di BEI tahun 2014-2018. Sampel penelitian sebanyak 69 perusahaan yang diambil menggunakan pruposive sampling dengan ketentuan berikut: (1) perusahaan jasa yang tecatat di BEI tahun 2016-2018; (2) selalu mengalami laba; (3) konsisten membagikan dividen. Analisis. data dilakukan dengan menggunakan aplikasi Warp-PLS 6.0 untuk menguji hipotesis yang telah diajukan.

Variabel dependen yang digunakan yaitu kebijakan dividen dengan dividend payout ratio sebagai alat ukurnya. Dividend payout ratio menunjukan kecenderungan perusahaan membayarkan dividen dengan menunjukan perbandingan antara jumlah pembayaran dividen dengan jumlah keuntungan bersih yang didapatkan oleh perusahaan. Rasio ini menujukan prosentase pendapatan keuntungan bersih perusahaan yang nantinya dibayarkan sebadai dividen. Menurut Gumanti (2013:22), dividend payout ratio dapat dirumuskan sebagai berikut:

$$
\text { Dividend Payout Ratio }=\frac{\text { Dividen per lembar }}{\text { Earningr per lembar }}
$$

Variabel independen yang digunakan yaitu rasio profitabilitas, rasio leverage dan rasio aktivitas. Rasio profitabilitas diukur menggunakan return on assets (ROA). Rasio ini menceriminkan besaranya kontribusi asset dalam memperoleh keeuntungan bersih atau laba bersih dan digunakan untuk mengukur besarnya jumlah laba bersih yang nantinya dihasilkan perusahaan dari setiap rupiah dana yang ada pada total asetnya. Menurut Fahmi (2014:81) ROA dapat diukur dengan rumus berikut:

$$
\mathrm{ROA}=\frac{\text { Laba bersih }}{\text { Total aset }}
$$


Ira Puspita Setyaningsih, Agus Sucipto

Rasio leverage dalam penelitian ini diukur menggunakan debt to assets ratio (DAR). Rasio ini membandingkan total utang dengan total asset perusahaan dan menujukan besarnya utang perusahaan yang digunakan untuk membiayai asset yang digunakan perusahaan dalam kegiatan operasionalnya. Menurut Hery (2016:162) DAR dapat ddihitung menggunakan rumus berikut:

$$
D A R=\frac{\text { Total utang }}{\text { Total a.e.t. }}
$$

Rasio aktivitas dalam penelitian diukur menggunkan total asstes turnover (TATO). Rasio ini menunjukan bagaimana perusahaan total aktiva untuk meningkatkan penjualan dan memperoleh keuntungan dengan seefektif mungkin. Menurut Sartono (2012:118) Rumus TATO yaitu:

$$
\text { TATO }=\frac{\text { Penjualan }}{\text { Total aktiva }}
$$

Variabel moderating yang digunakan yaitu ukuran perusahaan. Menuurt Brigham and Houston (2012:4) ukuran perusahaan bisa dikur menggunakan total penjualan, jumlah lab, total aktiva, dan beban. Salah satu alat ukur untuk menunjukan besar kecilnya perusahaan yaitu total aktiva yang dimiliki perusahaan. menurut Wahyuliza and Fahyani (2019) rumus ukuran perusahaan adalah sebagai berikut:

Ukuran perusahaan $=$ Ln Total Aset

\section{HASIL DAN PEMBAHASAN}

\section{Hasil}

\section{Evaluasi Outer Model}

Convergen validity dapat diketahui dari besar kecilnya nilai loading factor setiap indicator dengan syarat nilai loading factor $>0,7$ dapat dinyatakan valid dan signifikan adalah ketika nilai dari $p$-value $<0,05$. Berikut hasil combined loadings and cross-loadings:

Tabel 1. Output Combined Loading and Cross Loading

\begin{tabular}{lcccc}
\hline \multicolumn{1}{c}{ Variabel } & Indicator & Loading Factor & P-Value & Keretangan \\
\hline Profitabilitas & ROA & 1,000 & $<0,001$ & Valid \\
Leverage & DAR & 1,000 & $<0,001$ & Valid \\
Aktivitas & TATO & 1,000 & $<0,001$ & Valid \\
Ukuran Perusahaan & SIZE & 1,000 & $<0,001$ & Valid \\
Kebijakan Dividen & DPR & 1,000 & $<0,001$ & Valid \\
\hline
\end{tabular}

Berdasarkan tabel 1 seluruh indicator memenuhi syarat convergent validity dan dinyatakan valid. Hal tersebut ditunjukan dari besarya nilai loading vactor yang lebih besar dari 0,70. Selain melihat Combined Loading and Cross-Loadings, pengukuran Convergent Validity dapat dilihat melalui nilai AVE (Average Variance Extracted) dengan syarat $>0,50$. 
Moderasi Ukuran Perusahaan pada ...

Tabel 2. Output Latent Variable Coefficients

\begin{tabular}{lccc}
\hline \multicolumn{1}{c}{ Variabel Laten } & Nilai AVE & Kriteria & Keterangan \\
\hline Profitabilitas & 1,000 & $>0,50$ & Valid \\
Leverage & 1,000 & $>0,50$ & Valid \\
Aktivitas & 1,000 & $>0,50$ & Valid \\
Ukuran Perusahaan & 1,000 & $>0,50$ & Valid \\
Kebijakan Dividen & 1,000 & $>0,50$ & Valid \\
\hline
\end{tabular}

Berdasarkan tabel 2 menunjukan bahwa seluruh konstruk telah memenuhi convergent validity. Hal tersebut ditunjukan dari besarnya nilai AVE untuk setiap kontruk lebih besar dari 0,50 (AVE $>0,50$ ), sehingga seluruh variabel dinyatakan valid.

\section{Discriminant Validity}

Discriminant validity dapat dilihat dari loading konstruk laten. Jika hubungan kontsruk dengan pokok pengukuran (setiap indicator) lebih besar daripada ukuran konstruk lainnya maka validitas diskriminan terpenuhi. Berikut ini adalah hasil loading kostruk laten:

Tabel 3. Output Nilai Loading Konstruk Laten

\begin{tabular}{ccccccc}
\hline \multirow{2}{*}{ Indicator } & \multicolumn{5}{c}{ Nilai loading ke konstruk lainnya } & \multirow{2}{*}{ Keterangan } \\
\cline { 2 - 6 } & ROA & DAR & TATO & SIZE & DPR & \\
\hline ROA & $(1,000)$ & 0,000 & 0,000 & 0,000 & 0,000 & Valid \\
DAR & 0,000 & $(1,000)$ & 0,000 & 0,000 & 0,000 & Valid \\
TATO & 0,000 & 0,000 & $(1,000)$ & 0,000 & 0,000 & Valid \\
SIZE & 0,000 & 0,000 & 0,000 & $(1,000)$ & 0,000 & Valid \\
DPR & 0,000 & 0,000 & 0,000 & 0,000 & $(1,000)$ & Valid \\
\hline
\end{tabular}

Berdasarkan tabel 3 keseluruhan indicator telah memenuhi validitas diskriminan dan dinyatakan valid. Cara lain yang digunakan untuk mengevalusai discriminat validity yaitu menggunakan AVE. Jika akar kuadrat (square roots) AVE lebih tingi dari korelasi antar variabel laten pada kolom yang sama (atas atau bawahnya) maka validitas diskriminan terpenuhi. Berikut ini adalah hasil perhitungan AVE:

Tabel 4. Correlations Among Latent Variables

\begin{tabular}{cccccc}
\hline & ROA & DAR & TATO & SIZE & DPR \\
\hline ROA & $(1,000)$ & $-0,560$ & 0,128 & $-0,236$ & 0,150 \\
DAR & $-0,560$ & $(1,000)$ & $-0,087$ & 0,262 & $-0,088$ \\
TATO & 0,128 & $-0,087$ & $(1,000)$ & $-0,180$ & 0,030 \\
SIZE & $-0,236$ & 0,262 & $-0,180$ & $(1,000)$ & $-0,138$ \\
DPR & 0,150 & $-0,088$ & 0,030 & $-0,138$ & $(1,000)$ \\
\hline
\end{tabular}

Berdasarkan tabel 4 menunjukan bahwa kriteria validitas diskriminan telah terpenuhi dan menunjukan bahwa indicator tersebut mampu mengukur variabelnya secara tepat daripada dengan variabel lainnya. 
Ira Puspita Setyaningsih, Agus Sucipto

\section{Composite Reliability}

Uji reliabilitas konstruk dapat dilakukan dengan melihat composite reliability dan cronbach's alpha dengan syarat nilai composite reliability dan cronbach's alpha $>0,07$. Berikut ini hasil dari koefisien variabel laten:

Tabel 5. Hasil Output Latent Variable Coefficients

\begin{tabular}{ccccc}
\hline & Composite Reliability & Cronbach's Alpha & Kriteria & Keterangan \\
\hline ROA & 1,000 & 1,000 & $>0,70$ & Reliabel \\
DAR & 1,000 & 1,000 & $>0,70$ & Reliabel \\
TAT0 & 1,000 & 1,000 & $>0,70$ & Reliabel \\
SIZE & 1,000 & 1,000 & $>0,70$ & Reliabel \\
DPR & 1,000 & 1,000 & $>0,70$ & Reliabel \\
\hline
\end{tabular}

Tabel 5 menunjukan bahwa seluruh variabel memenuhi kriteria composite reliability dan dinyatakan reliable.

\section{Evaluasi Inner Model}

Evaluasi inner model dilakukan menlihat nilai R-Square digunakan untuk melihat tingkat signifikansi dari variabel latent. Selian itu juga dapat dilakuakn dengan melihat nilai Q-square yang biasanya disebut dengan Stoner-Geisse Coefficient untuk menilai validitas predektif atau relevansi dari sekumpulan variabel laten predictor pada variabel criterion. Nilai Q-square > 0 menunjukan bahwa model memiliki predictive relevance yang baik, sebaliknya jika nilai Q-square $<0$ menujukan model kurang memiliki predictive relevance. Hasil evaluasi inner model di tunjukan pada table dibawah.

Tabel 6. Hasil Evauasi Inner Model

\begin{tabular}{ll}
\hline R-Square & Q-Square \\
\hline 0,146 & 0,144 \\
\hline
\end{tabular}

Tabel 6 menunjukan bahwa besarnya nilai R-Square adalah 0,146 yang berarti 14,6\% varian dari variabel kebijakan dividen dapat dijelaskan oleh variabel profitabilitas, leverage, aktivitas dan interaksi profitabilitas dengan ukuran perusahaan, leverage dengan ukuran perusahaan dan aktivitas dengan ukuran perusahaan. Sementara sisanya yaitu $85,4 \%$ dijelaskna oleh variabel lain di luar model. Hasil yang disajikan pada tersebut juga menunjukan bahwa nilai Q-Square adalah 0,144 yang berarti model penelitian ini layak untuk menjelaskan variabel endogen yaitu kebijakan dividen yang ditunjukan dengan nilai Q-Square $>0$. 


\section{Hasil Pengujian Hipotesis}

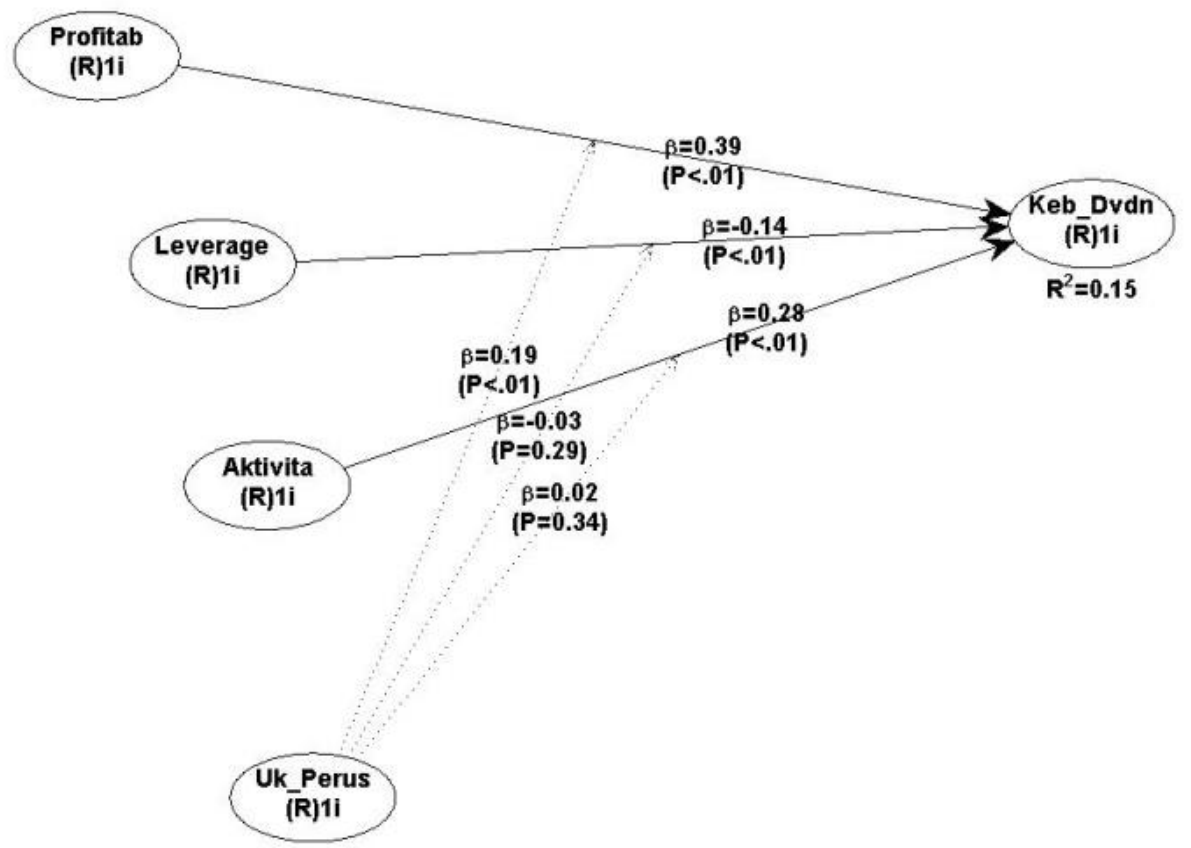

\section{Gambar 3. Hasil analisis PLS}

Pengujian hipotesis dilakukan dengan melihat hubungan antar kosntruk berdasarkan besarnya nilai path coefficients dan nilai p-value dalam menentukan signifikan atau tidaknya suatu hubungan. Pengaruh variabel terkait dikatakan signifikan jika loading factor disertai dengan nilai signifikansi kurang dari 0,05 (P-Value <0,05) (Hengki and Imam, 2014:78). Berikut hasil uji hipotesis:

\section{Tabel 7. Hasil Pengujian Hipotesis}

\begin{tabular}{lccc}
\hline \multicolumn{1}{c}{ Variabel } & $\begin{array}{c}\text { Koefisien } \\
\text { Jalur }(\beta)\end{array}$ & P-value & Keterangan \\
\hline Profitabilitas $\rightarrow$ Kebijakan Dividen & 0,39 & $<0.01$ & Signifikan \\
Leverage $\rightarrow$ Kebijakan Dividen & $-0,14$ & $<0.01$ & Signifikan \\
$\begin{array}{l}\text { Aktivitas } \rightarrow \text { Kebijakan Dividen } \\
\text { Profitabilitas*Ukuran Perusahaan }\end{array}$ & 0,28 & $<0.01$ & Signifikan \\
$\begin{array}{l}\rightarrow \text { Kebijakan Dividen } \\
\begin{array}{l}\text { Leverage*Ukuran Perusahaan } \\
\rightarrow \text { Kebijakan Dividen }\end{array}\end{array}$ & 0,19 & $<0,01$ & Signifikan \\
$\begin{array}{l}\text { Aktivitas*Ukuran Perusahaan } \\
\rightarrow \text { Kebijakan Dividen }\end{array}$ & $-0,03$ & 0,29 & $\begin{array}{c}\text { Tidak } \\
\text { Signifikan } \\
\text { Tidak } \\
\text { Signifikan }\end{array}$ \\
\hline
\end{tabular}

Tabel 7 menunjukan bahwa nilai koefisien jalur (path coefficient) dari profitabilitas menuju kebijakan dividen adalah 0,39 dengan p-value $<0.01$ sehingga kebijakan dividen dipengaruhi profitabilitas secara signifikan. Hasil penelitian ini menerima $\mathrm{H} 1$ yaitu profitabilitas memiliki pengaruh positif signifikan terhadap kebijakan dividen. 
Ira Puspita Setyaningsih, Agus Sucipto

Nilai koefisien jalur (path coefficient) dari leverage menuju kebijakan dividen sebesar -0,14 dengan p-value <0,001 sehingga kebijakan dividen dipengaruhi leverage secara signifikan. Hasil penelitian ini menerima $\mathrm{H} 2$ yaitu leverage memiliki pengaruh negative signifikan terhadap kebijakan dividen.

Nilai koefisien jalur (path coefficient) dari rasio aktivitas menuju kebijakan dividen sebesar 0,28 dengan p-value $<0,001$ sehingga kebijakan dividen dipengaruhi leverage secara signifikan. Hasil penelitian ini menerima H3 yaitu rasio aktivitas memiliki pengaruh negative signifikan terhadap kebijakan dividen.

Nilai koefisien jalur (path coefficient) dari profitabilitas dimoderasi ukuran perusahaan menuju kebijakan dividen sebesar 0,19 dengan p-value $<0,001$ sehingga ukuran perusahaan memoderasi pengaruh proditabilitas terhadap kebijakan dividen. Hasil penelitian ini menerima H4 yaitu ukuran perusahaan mampu memoderasi hubungan profitabilitas terhadap kebijakan dividen.

Nilai koefisien jalur (path coefficient) dari leverage dimoderasi ukuran perusahaan menuju kebijakan dividen sebesar -0,03 dengan p-value 0,29 sehingga ukuran perusahaan tidak memoderasi pengaruh leverage terhadap kebijakan dividen. Hasil penelitian ini menolak H5 yaitu ukuran perusahaan mampu memoderasi hubungan leverage terhadap kebijakan dividen.

Nilai koefisien jalur (path coefficient) dari rasio aktivitas dimoderasi ukuran perusahaan menuju kebijakan dividen sebesar 0,02 dengan p-value 0,34 sehingga ukuran perusahaan tidak memoderasi pengaruh rasio aktivitas terhadap kebijakan dividen. Hasil penelitian ini menolak H6 yaitu ukuran perusahaan mampu memoderasi hubungan rasio aktivitas terhadap kebijakan dividen.

\section{Pembahasan \\ Rasio Profitabilitas terhadap Kebijakan Dividen}

Hasil pengujian H1 menunjukan bahwa kebijakan dividen dipengaruhi secara positif dan signifikan oleh profitabilitas. Semakin besar keuntungan yang diperoleh maka akan semakin besar pula kemampuan perushaan untuk membayarkan dividen. Hasil ini sesuai dengan teori Sartono (2012:122) yang menyatakan bahwa semakin besar nilai return on assets perusahaan maka kemungkinan pembagian dividen juga akan semakin besar. Perusahaan yang ingin membayarkan dividen dalam jumlah yang besar harus memperhatikan tingkat profitabilitasnya, dengan terus meningkatkan profitabilitasnya maka dividen yang akan dibayarkan perusahaan juga akan semakin besar. Begitu juga dengan investor yang mengharapkan dividen yang besar, maka harus memperhatian tingkat profitabilitas perusahaan yang akan dipilih sebagai obyek investasinya. Hasil penelitian ini sejalan dengan hasil penelitian yang ditemukan oleh Singla and Samanta (2018); Abor and Bokpin (2010); Mardiyati, Nusrati, and Hamidah (2014); Lestari (2017); Daud (2015); Narindro and Basri (2019); Thakur and Kannadhasan (2018); Issa (2015); Ahmad and Wardani (2014); Ahmed, Rafay, and Ahmed (2018); Arko et al. (2014); Fitri, Hosen, And Muhari (2016); Muhammadinah and Jamil (2015); Tahu et al. (2017) yang menyatakan kebijakan dividen dipengaruhi secara positif dan signifikan oleh rasio profitabilitas. 


\section{Rasio Leverage terhadap Kebijakan Dividen}

Moderasi Ukuran Perusahaan pada...

Berdasarkan hasil pengujian H2 menunjukan bahwa kebijakan dividen di[engaruhi secara negative dan signifikan oleh rasio leverage. Hal ini berarti semakin besar nilai leverage perusahaan maka dividen yang dibayarkan perusahaan tersebut akan semakin kecil. Perusahaan dengan penggunaan utang yang tinggi akan membayarkan dividen yang kecil karena karena sebagian besar keuntungan yang diperoleh akan digunakan untuk memenuhi utangnya. Hasil ini sesuai dengan teori yang dikemukanan Gumanti (2013:83) bahwa perusahaan dengan tingkat utang besar dan harus dibayar segera, akan mengurangi jumlah pembayaran dividennya atau menunda pembayarannya. Perusahaan yang ingin membayarkan dividen dalam jumlah besar harus dapat mengurangi tingkat leveragenya, karena apabila tingkat leverage perusahaan tersebut tinggi maka dividen yang yang akan dibayarkan juga semakin kecil. Investor dapat emnggunakan rasio leverage sebagai bahan pertimbangan sebelum menentukan pilihan investasinya, terutama investor yang mengaharpkan pembayaran dividen yang tinggi harus memilih perusahaan yang tingkat leveragenya rendah. Hasil penelitian ini sejalan dengan hasil penelitian yang ditemukan oleh Al-Kayed (2017); Yusof and Ismail (2016); Hasnawati (2017); Jabbouri (2016); Kuzucu (2015); Ahmad and Wardani (2014); Trisna and Gayatri (2019); Arko et al. (2014);Kaźmierska-Jóźwiak (2015) menemukan kebijakan dividen dipengaruhi secara negative dan signifikan oleh rasio leverage.

\section{Rasio Aktivitas terhadap Kebijakan Dividen}

Berdasarkan hasil pengujian H3 menunjukan kebijakan dividen dipengaruhi secara positif dan signifikan oleh rasio aktivitas. Perusahaan dengan nilai rasio aktivitas tinggi akan menbayrakan dividen dalam jumlah besar. Hasil ini menunjukan bahwa penggunaan total aktiva yang dimiliki perusahaan dalam penghasilkan penjualan sudah efektif, sehingga semakin tingi rasio aktivitasnya menunjukan bahwa manajemen perusahaan dalam kondisi yang baik. Sebaliknya, apabila nilai rasio ini semakin kecil maka menunjukan bahwa manajemen perusahaan kurang efektif sehingga memerlukan evalasi strategi, pemasaran dan pengeluaran modal yang digunakan untuk investasi (Hanafi and Halim 2010:81). Perusahaan harus meningkatkan aktivitasnya agar dapat membayarkan dividen dalam jumlah yang besar, semakin besar dividen yang dibayarkan maka investor juga akan semakin tertarik untuk menginvestasikan modalnya pada perusahaan tersebut. Semakin naik aktivitas maka dividen yang akan dibayarkan juga akan semakin naik, begitu juga sebaliknya. Hasil penelitiaan ini mendukung penelitian yang dilakukan Muhammadinah and Jamil (2015); Firdaus and Handayani (2019); Simanjuntak (2016); Sampurna and Widyarti (2015); Purwanti and Sawitri (2011) dan Sabri, Deviyanti, and Kurniawan (2018) yang menemukan kebijakan dividen dipengaruhi secara positif dan signifikan oleh rasio aktivitas. 
Ira Puspita Setyaningsih, Agus Sucipto

Ukuran Perusahaan Memoderasi Pengaruh Rasio Profitabilitas terhadap Kebijakan Dividen

Berdasarkan hasil pengujian $\mathrm{H} 4$ menunjukan bahwa ukuran perusahaan memoderasi pengaruh profitabilitas terhadap kebijakan dividen secara signifikan dengan arah positif. Hasil tersebut menunjukan bahwa ukuran perusahaan mampu memperkuat pengaruh profitabilitas terhadap kebijakan dividen pada perusahaan jasa di Indonesia tahun 2014-2018. Hasil ini mengindikasikan bahwa tingginya tingkat profitabilitas yang diiringi dengan besarnya ukuran perusahaan maka akan mendorong peningkatan jumlah dividen yang dibayarkan perusahaan. Perusahaan yang berukuran besar memiliki profitabilitas yang lebih besar dibandingkan dengan perusahaan yang berukuran kecil. Hal ini terjadi karena perusahaan dengan ukuran yang besar dianggap lebih stabil dan lebih mampu menghasilkan laba serta memiliki memiliki arus kas yang positif dibandingkan perusahaan kecil. Oleh karena itu, perusahaan yang ingin membayarkan dividen dalam jumlah besar harus meningkatkan profitabilitasnya yang tinggi disertai dengan semaikn besarnya ukuran perusahaan tersebut. Hasil ini sejalan dengan teori Brealey, Myers, and Marcus (2008:51) yang menyatakan bahwa kebijakan pembayaran dividen merupakan sesuatu yang mahal dan hanya dapat dilakukan oleh perusahaan yang memiliki ketersediaan kaslah yang melakukan pembayaran dividen. Perusahaan yang memiliki asset yang sedikit cenderung akan membayarkan dividen dalam jumlah yang kecil karena laba yang diperoleh perusahaan dialokasikan sebagai laba ditahan guna menambah persediaan aset perusahaan, sehingga hanya perusahaan yang berukuran besar dan memiliki ketersediaan kas yang cukup yang mampu membayarkan dividen dalam jumlah besar. Selain itu hasil penelitiaan ini juga sejalan dengan penelitian yang dilakuakn oleh Arseto and Jufrizen (2018) yang menyatakan bahwa ukuran perusahaan memoderasi hubungan profitabilitas terhadap kebijakan pembayaran dividen.

\section{Ukuran Perusahaan Memoderasi Pengaruh Rasio Profitabilitas terhadap Kebijakan Dividen}

Berdasarkan hasil pengujian H5 menunjukan bahwa ukuran perusahaan tidak mampu memoderasi hubungan leverage terhadap kebijakan dividen. Hasil ini mengindikasikan bahwa besar kecilnya ukuran perusahaan tidak mampu memperkuat atau memperlemah pengaruh leverage terhadap kebijakan dividen perusahaan jasa di Indonesia tahun 2014-2018. Ukuran perusahaan tidak mampu memoderasi pengaruh leverage terhadap kebijakan dividen dikarenakan ukuran perusahaan yang besar tidak dapat menjamin kelangsungan hidup perusahaan maupun kelancaran aktivitas operasional perusahaan. Meskipun perusahaan yang berukuran besar memiliki kemudahan dalam aksesnya kepasar modal, tetapi belum tentu perusahaan tersebut dapat dengan memperoleh dana di pasar modal karena investor tentu memiliki banyak pertimbangan sebelum menanamkan dananya pada suatu perusahaan. Oleh karena itu dalam penelitian ini besar kecilnya ukuran perusahaan tidak mampu memperkuat pengaruh leverage terhadap kebijakan dividen. 
Moderasi Ukuran Perusahaan pada...

Hasil penelitian ini menunjukan bahwa perusahaan tidak perlu memperhatikan ukuran perusahaannya jika ingin mengurangi tingkat leverage agar dapat membayarkan dividen tinggi, sebab besar kecilnya ukuran perusahaan tidak akan mempengaruhi dampak yang diberikan leverage terhadap kebijakan dividen perusahaan, sehingga ukuran perushaan bukanlah faktor yang harus dipertimbangan dalam menyusun strategi perusahaan. Ada atau tidak adanya ukuran perusahaan tidak akan memberikan pengaruh pada hubungan antara leverage terhadap kebijakan dividen peerusahaan. Selain itu, investor yang menginginkan pembayaran dividen yang tinggi juga tidak perlu menjadikan ukuran perusahaan sebagai bahan prtimbangan sebelum melakukan investasi pada suatu perusahaan yang memiliki tingkat leverage tinggi atau rendah karena ukuran perusahaan tidak mampu memberi pengaruh terhadap dampak leverage dalam mempengaruhi kebijakan dividen. Hasil penelitian ini bertentangan dengan penemuan Trisna and Gayatri (2019) yang menunjukan bahwa pengaruh leverage terhadap kebijakan dividen mampu dimoderasi oleh ukuran perusahaan.

Ukuran perusahaan memoderasi pengaruh rasio aktivitas terhadap kebijakan dividen. Berdasarkan hasil pengujian H6 menunjukan bawha ukuran perusahaan tidak mampu memoderasi hubungan rasio aktivitas terhadap kebijakan dividen. Hasil ini mengindikasikan bahwa besar kecilnya ukuran perusahaan tidak mampu memperkuat atau memperlemah pengaruh rasio aktivitas terhadap kebijakan dividen perusahaan jasa di Indonesia tahun 2014-2018. Tingginya tingkat rasio aktivitas yang diiringi dengan besarnya ukuran perusahaan tidak akan mendorong penurunan atau kenaikan jumlah dividen yang dibayarkan perusahaan. Ukuran perusahaan yang besar tidak dapat menjamin perusahaan mampu memaksimalkan total asetnya untuk menghasilkan pendapatan yang besar, sehingga ukuran perusahaan tidak mampu memoderasi pengaruh antara rasio aktifitas yang di proksikan oleh total assets turnover terhadap kebijakan dividen perusahaan.

Hasil penelitian ini menunjukan bahwa perusahaan tidak perlu memperhatikan ukuran perusahaannya jika ingin membayarkan dividen yang tinggi sebab esar kecilnya ukuran perusahaan tidak akan mempengaruhi dampak yang diberikan rasio aktivitas terhadap kebijakan dividen perusahaan. Ada atau tidak adanya ukuran perusahaan tidak akan memberikan pengaruh pada hubungan antara rasio aktivitas terhadap kebijakan dividen peerusahaan. Selain itu, investor yang menginginkan pembayaran dividen yang tinggi juga tidak perlu menjadikan ukuran perusahaan sebagai bahan prtimbangan sebelum melakukan investasi pada suatu perusahaan yang memiliki tingkat rasio aktivitas tinggi atau rendah. Hal ini dikarenakan ukuran perusahaan tidak mampu memberi pengaruh terhadap dampak rasio aktivitas dalam mempengaruhi kebijakan dividen, sehingga besar kecilnya jumlah pembayaran dividen yang dipengaruhi oleh rasio aktivitas yang diproksikan oleh total assets turnover tidak ada akan terpengaruh dengan besar kecilnya ukuran perusahaan tersebut. 
Ira Puspita Setyaningsih, Agus Sucipto

\section{SIMPULAN}

Penelitian ini menemukan profitabilitas berpengaruh positif signifikan terhadap kebijakan dividen, semakin besar tingkat rasio profitabilitas maka jumlah dividen yang dibayarkan perusahaan juga semakin besar. Leverage berpengaruh negative signifikan terhadap kebijakan dividen, semakin besar tingkat rasio leverage maka jumlah dividen yang dibayarkan perusahaan akan semakin kecil. Rasio aktivitas berpengaruh positif signifikan terhadap kebijakan dividen, semakin besar tingkat rasio aktivitas maka jumlah dividen yang dibayarkan perusahaan juga semakin besar. Ukuran perusahaan mampu memperkuat pengaruh profitabilitas terhadap kebijakan dividen. Tingginya tingkat profitabilitas perusahaan diiringi oleh semakin besarnya ukuran perusahaan akan berdampak pada pengingkatan jumlah dividen yang dibayarkan. Ukuran perusahaan tidak mampu memperkuat pengaruh leverage terhadap kebijakan dividen karena ukuran perusahaan yang besar tidak menjamin kelangsungan hidup perusahaan maupun kelancaran aktivitas operasional perusahaan. Ukuran perusahaan tidak mampu memoderasi hubungan rasio aktivitas terhadap kebijakan dividen karena ukuran perusahaan yang besar tidak dapat menjamin perusahaan mampu memaksimalkan total asetnya untuk menghasilkan pendapatan yang besar. Perusahaan sector jasa yang ingin membagikan dividen dalam jumlah besar harus meningkatkan nilai profitabilitas dan rasio aktivitasnya agar laba bersih perusahaan semakin besar, selain itu perusahaan juga harus menurunkan tingkat rasio leveragenya dengan mengurangi tingkat hutangnya. Investor pada perusahaan sector jasa harus memilih perusahaan dengan nilai profitabilis dan aktivitas yang tinggi serta leverage yang rendah agar mendapatkan nilai pembagian dividen yang tinggi. Selain itu perusahaan dengan ukuran besar akan mendorong tingginya nilai profitabilitas perusahaan tapi belum tentu dapat meningkatkan aktivitasnya dan memperkecil leveragenya, sehingga investor tidak harus memperhatikan ukuran suatu perusahaan. Untuk penelitian selanjutnya di harapkan menambah jangka waktu periode pngamatan menjadi kurang lebih sepuluh tahun serta memeperbanyak variable pengamatan seperti rasio likuiditas, nilai perusahaan ataupun faktor makro ekonomi serta memperluas objek peneliian untuk mendapatkan hasil yang lebih akurat.

\section{DAFTAR PUSTAKA}

Abor, J., \& Bokpin, G. A. (2010). Investment opportunities, corporate finance, and dividend payout policy: Evidence from emerging markets. Studies in Economics and Finance, 27(3), 180-194. https://doi.org/10.1108/10867371011060018

Ahmad, G. N., \& Wardani, V. K. (2014). The Effect of Fundamental Factor To Dividend Policy: Evidence in Indonesia Stock Exchange. International Journal of Business and Commerce, 4(02), 14-25. www.ijbcnet.com

Ahmed, F., Rafay, A., \& Ahmed, A. (2018). Dividend Payout Policy of Conventional Banking and Islamic Banking in Pakistan. Al-Iqtishad: Jurnal Ilmu Ekonomi Syariah, 10(1), 135-152. https://doi.org/10.15408/aiq.v10i1.6103

Ahmed, I. E. (2015). Liquidity, Profitability and the Dividends Payout Policy. 
Moderasi Ukuran Perusahaan pada...

World Review of Business Research, 5(2), 73-85.

Al-Kayed, L. T. (2017). Dividend payout policy of Islamic vs conventional banks: case of Saudi Arabia. International Journal of Islamic and Middle Eastern Finance and Management, 10(1), 117-128. https://doi.org/10.1108/IMEFM-09-2015-0102

Ali, A., Fengju, X., \& Goncalves De Andrade, A. (2015). Determinants of Dividend Policy: Evidence From Textile Industry of Pakistan. International Journal of Arts \& Sciences, 08(08), 45-52. https://doi.org/10.7819/rbgn.v17i54.

Arko, A. C., Abor, J., Adjasi, C. K. ., \& Amidu, M. (2014). What influence dividend decisions of firms in Sub-Saharan African? Journal of Accounting in Emerging Economies, 4(1), 57-78. https://doi.org/10.1108/jaee-122011-0053

Arseto, D. D., \& Jufrizen, J. (2018). Pengaruh Return On Asset dan Current Ratio Terhadap Dividen Payout Ratio Dengan Firm Size Sebagai Variabel Moderating Kebijakan dividen perusahaan tergambar pada Dividend Payout Ratio yaitu merupakan presentasi laba yang dibagikan dalam bentuk dividen tun. Jurnal Ilmiah Magister Manajemen, 1(1), 15-30.

Baker, H. K., Dewasiri, N. J., Yatiwelle Koralalage, W. B., \& Azeez, A. A. (2018). Dividend policy determinants of Sri Lankan firms: a triangulation approach. Managerial Finance, 45(1), 2-20. https://doi.org/10.1108/MF03-2018-0096

Brealey, R. A., Myers, S. C., \& Marcus, A. J. (2008). Dasar-dasar Manajemen Keuangan Perusahaan Jilid 2 (Edisi Keli). Erlangga.

Brigham, E. F., \& Houston, J. F. (2012). Dasar-dasar Manajemen Keuangan (Edisi Kese). Salemba Empat.

Daud, M. N. (2015). Analisis Faktor-Faktor yang Mempengaruhi Rasio Pembayaran Dividen pada PT . Indofood Sukses Makmur di Bursa Efek Indonesia ( BEI ). Jurnal Manajemen Dan Keuangan, 4(1), 262-278.

Dewasiri, N. J., Yatiwelle Koralalage, W. B., Abdul Azeez, A., Jayarathne, P. G. S. A., Kuruppuarachchi, D., \& Weerasinghe, V. A. (2019). Determinants of dividend policy: evidence from an emerging and developing market. Managerial Finance, 45(3), 413-429. https://doi.org/10.1108/MF-092017-0331

Enow, S. T., \& Isaacs, E. B. H. (2018). Factors that Determine Dividend Payout . Evidence from the Financial Service Sector in South Africa. Journal of Banking and Finance Management, 1(1), 48-53.

Fahmi, I. (2014). Analisis Laporan Keuangan. Alfabeta.

Firdaus, I., \& Handayani, P. (2019). Pengaruh DER, TATO dan NPM Terhadap Kebijakan Dividen (Studi Kasus Pada Industri Dasar dan Kimia yang Terdaftar Di Bursa Efek Indonesia (BEI) Tahun 2012-2016). JAAF (Journal of Applied Accounting and Finance), 3(1), 71-84. https://doi.org/10.33021/jaaf.v3i1.679

Fitri, R. R., Hosen, M. N., \& Muhari, S. (2016). Analysis of Factors that Impact Dividend Payout Ratio on Listed Companies at Jakarta Islamic Index. International Journal of Academic Research in Accounting, Finance and Management Sciences, 6(2), 87-97. https://doi.org/10.6007/ijarafms/v6- 
Ira Puspita Setyaningsih, Agus Sucipto

i2/2074

Gumanti, T. A. (2013). Kebijakan Dividen Teori, Empiris, dan Implikasi. UPP STIM YKPN.

Hanafi, \& Halim. (2010). Manajemen Keuangan Internasional. BPFE.

Handayani, K. M., Indarti, I., \& Listiyowati. (2019). Pengaruh Kinerja Keuangan dan Ukuran Perusahaan terhadap Harga Saham dengan Kebijakan Dividen sebagai Variabel Intervening pada Perusahaan Manufaktur yang Terdaftar di Bursa Efek Indonesia. Jurnal Ilmiah Aset, 21(2), 93-105.

Hasnawati, S. (2017). Kebijakan Dividen Di Bursa Efek Indonesia Pada Perusahaan Kelompok Lq 45. Jurnal Manajemen, 21(1), 132-145. https://doi.org/10.24912/jm.v21i1.152

Hengki, \& Imam. (2014). Partial Least Square Konsep, Metode dan Aplikasi menggunakan Program WarpPLS 4.0 (Edisi 2). Badan Penerbit Universitaas Diponegoro.

Hery. (2016). Analisis Laporan Keuangan, Integrated and Comprehensive Edition. Grasindo.

Hidayatullah, M. S. (2019). OPINI: Sektor Jasa, Mesin Baru Pertumbuhan Ekonomi.

https://opini.harianjogja.com/read/2019/07/19/543/1006496/opinisektor-jasa-mesin-baru-pertumbuhan-ekonomi

Horne, J. C. Van, \& Wachowicz Jr, J. M. (2012). Prinsip-Prinsip Manajemen Keuangan (Edisi Keti). Salemba Empat.

Issa, A. I. F. (2015). The Determinants of Dividend Policy: Evidence from Malaysian Firms. Research Journal of Finance and Accounting Www.Iiste.Org ISSN, 6(18), 69-87. http://ssrn.com/abstract=2770541

Jabbouri, I. (2016). Determinants of corporate dividend policy in emerging markets: Evidence from MENA stock markets. Research in International Business and Finance, 37, 283-298. https://doi.org/10.1016/j.ribaf.2016.01.018

Kasmir. (2012). Analisis Laporan Keuangan. Raja Grafindo Persada.

Kaźmierska-Jóźwiak, B. (2015). Determinants of Dividend Policy: Evidence from Polish Listed Companies. Procedia Economics and Finance, 23, 473477. https://doi.org/10.1016/s2212-5671(15)00490-6

Khan, M. N., \& Shamim, M. (2017). A sectoral analysis of dividend payment behavior: Evidence from Karachi Stock Exchange. SAGE Open, 7(1), 1-13. https://doi.org/10.1177/2158244016682291

Kuzucu, N. (2015). Determinants of Dividend Policy: A Panel Data Analysis for Turkish Listed Firms. International Journal of Business and Management, 10(11), 149-160. https://doi.org/10.5539/ijbm.v10n11p149

Lestari, D. (2017). Perusahaan, Dan Kebijakan Dividen. Jurnal Riset Manajemen Dan Bisnis (JRMB) Fakultas Ekoonomi UNIAT, 2, 227-240.

Mardiyati, U., Nusrati, D., \& Hamidah. (2014). Pengaruh Free Cash Flow, Return on Assets, Total Assets Turnover Dan Sales Growth Terhadap Dividend Payout Ratio ( Studi Pada Perusahaan Manufaktur Yang Terdaftar Di Bursa Efek Indonesia Periode 2008-2012 ). Jurnal Riset Manajemen Sains Indonesia (JRMSI), 5(2), 204-221.

Marlim, P., \& Arifin, A. Z. (2015). Analysis of cash position, debt to equity ratio, return on assets, growth potential, and total assets turn over effect to 
Moderasi Ukuran Perusahaan pada... dividend pay out ratio on companies listed at Indonesia stock exchange 2009-2011. International Journal of Applied Business and Economic Research, 13(7), 5403-5419.

Mehta, A. (2012). An Empirical Analysis of Determinants of Dividend Policy Evidence from the UAE Companies. Global Review of Accounting and Finance, 3(1), 18-31.

Muhammadinah, \& Jamil, M. A. (2015). Pengaruh Current Ratio, Debt To Equity Ratio, Total Asset Turnover Dan Return on Asset Terhadap Dividen Payout Ratio Pada Perusahaan Sektor Industri Barang Konsumsi Yang Terdaftar Di Bursa Efek Indonesia. I-Economics, 1(1), 1-20.

Narindro, L., \& Basri, H. (2019). Assessing determinants of dividend policy of the government-owned companies in Indonesia. International Journal of Law and Management, 61(5-6), 530-541. https://doi.org/10.1108/IJLMA-09-2017-0215

Nerviana, R. (2015). The effect of financial ratios and company size on dividend policy. The Indonesian Accounting Review, 5(1), 23-32. https://doi.org/10.14414/tiar.v5i1.486

Patra, T., Poshakwale, S., \& Ow-Yong, K. (2012). Determinants of corporate dividend policy in Greece. Applied Financial Economics, 22(13), 10791087. https://doi.org/10.1080/09603107.2011.639734

Purwanti, D., \& Sawitri, P. (2011). Dampak Rasio Keuangan Terhadap Kebijakan Deviden. Jurnal Bisnis Dan Manajemen, 3(2), 125-134.

Rahmawati, N. D., Saerang, I. S., \& Rate, P. Van. (2014). Kinerja Keuangan Pengaruhnya Terhadap Kebijakan Dividen Pada Perusahaan Bumn Di Bursa Efek Indonesia. Jurnal Riset Ekonomi, Manajemen, Bisnis Dan Akuntansi, 2(2), 1306-1317.

Sabri, F. H., Deviyanti, D. R., \& Kurniawan, I. S. (2018). Pengaruh kinerja keuangan terhadap dividend payout ratio studi empiris pada perusahaan BUMN. Kinerja, 14(1), 24-30. https://doi.org/10.29264/jkin.v14i1.2446

Sampurna, C. D., \& Widyarti, E. T. (2015). Pengaruh Investment Opportunity Set, Debt to Equity Ratio, Growth, Earnings per Share, Total Assets Turnover Terhadap Dividend Payout Ratio (Pada Perusahaan Manufaktur Go Public di BEI Periode 2011-2013). Diponegoro Journal of Management, 4(02), $1-15$. https://ejournal3.undip.ac.id/index.php/djom/article/viewFile/13163/1 2721

Sartono, A. (2012). Manajemen Keuangan Teori dan Aplikasi. (Edisi Keem). BPFE.

Simanjuntak, S. M. (2016). Pengaruh Return On Asset, Growth , Total Asset Turnover, Ownership , Firm Size Dan Debt To Total Asset Terhadap Dividend Payout Ratio Pada Perusahaan Yang Terdaftar Di Bursa Efek Indonesia. Jurnal Lentera Akuntansi, 2(2), 101-116.

Singla, H. K., \& Samanta, P. K. (2018). Determinants of dividend payout of construction companies: a panel data analysis. Journal of Financial Management of Property and Construction, 24(1), 19-38. https://doi.org/10.1108/JFMPC-06-2018-0030

Tahu, P. G., Wiagustini, N. L. P., Artini, L. G. S., \& Rahyuda, H. (2017). Anteseden 
Ira Puspita Setyaningsih, Agus Sucipto

Dividend Policy on Manufacturing Industry in Indonesia Stock Exchange. Research Journal of Finance and Accounting, 8(18), 99-113. www.iiste.org Thakur, B. P. S., \& Kannadhasan, M. (2018). Determinants of dividend payout of Indian manufacturing companies: A quantile regression approach. Journal of Indian Business Research, 10(4), 364-376. https://doi.org/10.1108/JIBR-02-2018-0079

Trisna, I. K. E. R., \& Gayatri. (2019). Ukuran Perusahaan Memoderasi Pengaruh Free Cash Flow dan Leverage Terhadap Kebijakan Dividen. E-Jurnal Akuntansi Universitas Udayana, 26(1), 484-509. https://doi.org/10.24843/eja.2019.v26.i01.p18

Wahyuliza, S., \& Fahyani, R. (2019). Pengaruh Pertumbuhan Perusahaan, Ukuran Perusahaan, Struktur Modal Dan Return on Equity Terhadap Kebijakan Dividen Pada Perusahaan Manufaktur Yang Terdaftar Di Bursa Efek Indonesia. Jurnal Benefita, 4(1), 78-86. https://doi.org/10.22216/jbe.v1i1.3388

Yusof, Y., \& Ismail, S. (2016). Determinants of dividend policy of public listed companies in Malaysia. Review of International Business and Strategy, 26(1), 88-99. https://doi.org/10.1108/RIBS-02-2014-0030 